\section{VIVIENDA SOCIAL Y ESTRATEGIAS DE SOBREVIVENCIA. SOLUCIONES ADECUADAS A PARTIR DE UN ESTUDIO DE CASO (RESISTENCIA, ARGENTINA, 2013) ${ }^{1}$}

Miguel Ángel Barreto², María Andrea Benítez³, María Laura Puntel ${ }^{4}$

\section{Resumen}

Las soluciones habitacionales estatales argentinas no dan respuestas adecuadas a las necesidades de los hogares de bajos ingresos que utilizan las viviendas sociales para habitar y para realizar actividades económicas informales de sobrevivencia. Estos hogares trasforman las viviendas provistas por la ayuda social en unidades domésticas de reproducción y de producción de la vida, con consecuentes efectos negativos en la calidad de vida y en las condiciones de habitabilidad de estas viviendas. El siguiente artículo analiza este problema a partir de un estudio de caso localizado en la ciudad de Resistencia (Argentina) desde una

\section{SOCIAL HOUSING AND SURVIVAL SKILLS. APPROPRIATE SOLUTIONS PROVIDED BY A CASE STUDY (RESISTENCIA, ARGENTINA, 2013) ${ }^{1}$}

Miguel Ángel Barreto², María Andrea Benítez ${ }^{3}$, María Laura Puntel ${ }^{4}$

\section{Abstract}

In Argentina housing solutions do not properly meet the needs of low-income households that use social housing both as a dwelling and for the development of informal economic activities necessary for their survival. Households in these conditions transform the public housing into domestic units of production and reproduction of life, with consequent negative effects on living conditions and the quality of life of these homes. This paper analyzes this issue from a comprehensive and complex approach to habitat by investigating a case study in the city of 
perspectiva integral y compleja del hábitat, con la finalidad de extraer aportes que contribuyan con la política habitacional para la resolución adecuada del problema en favor de un hábitat digno.

\section{PALABRAS CLAVES: VIVIENDA SOCIAL, ESTRATEGIAS DE SOBREVIVENCIA, SOLUCIONES INTEGRALES.}

Fecha de recepción: 05-06-2014

Fecha de aceptación: 20-01-2015

1 Este trabajo es resultado del Plan de Trabajo de una beca de investigación denominado "Vivienda social y estrategias de sobrevivencia. Estudio de un caso en el AMGR", encuadrado en el proyecto "Cuantificación y tipificación de Áreas Urbanas Deficitarias Críticas para la intervención integral del hábitat social del Gran Resistencia". PI 12SC01 de la Universidad Nacional del Nordeste (2013-2016).

2 Argentina. Arquitecto, Magister y Doctor en Antropología social. Investigador independiente del Consejo Nacional de Investigaciones Científicas y Técnicas de Argentina (CONICET). Profesor titular de la Facultad de Arquitectura de la Universidad Nacional del Nordeste. Correo electrónico: mabarreto@arnet. com.ar.

3 Argentina. Arquitecta, Magister en Epistemología y Metodología de la Investigación científica. Investigadora y profesora adjunta de la Universidad Nacional del Nordeste, Directora del Instituto de Investigación y Desarrollo en Vivienda (IIDVI), Facultad de Arquitectura y Urbanismo de la Universidad Nacional del Nordeste. Correo electrónico: abmaria@hotmail.com

4 Argentina. Arquitecta, becaria de iniciación de la Universidad Nacional del Nordeste. Lugar de trabajo: Instituto de Investigación y Desarrollo en Vivienda (IIDVI), Facultad de Arquitectura y Urbanismo de la Universidad Nacional del Nordeste. Correo electrónico: lau_mp8@hotmail.com
Resistencia (Argentina). The aim of this research is to generate contributions that may influence public housing policies and provide appropriate solutions for the achievement of decent housing. KEYWORDS: SOCIAL HOUSING, SURVIVAL SKILLS, COMPREHENSIVE SOLUTIONS

\author{
Received: 05-06-2014
}

Accepted: 20-01-2015

1 This paper is part of the research fellowship "Social Housing and Survival Skills. A Case Study in AMGR", which is framed within the research project "Quantification and Classification of Poor Urban Areas for the Comprehensive Integration of Social Habitat in Greater Resistencia" PI 12SC01, Northeast National University (2013-2016).

2 Argentina. Architect, MSc and PhD in Social Anthropology. Independent researcher at CONICET and professor at the Faculty of Architecture and Urban Planning, Northeast National University.Email: mabarreto@arnet.com.ar

3 Argentina. Architect, MSc in Epistemology and Methodology of Scientific Research. Researcher and assistant professor at the Northeast National University. Head of the Institute of Research and Development in Housing (IIDVI) at the Faculty of Architecture and Urban Planning, Northeast National University. Email: abmaria@hotmail.com.

4 Argentina. Fellowship student at Institute of Research and Development in Housing (IIDVI), Faculty of Architecture and Urban Planning, Northeast National University. Email: lau_mp8@hotmail.com. 


\section{Vivienda social y estrategias de sobrevivencia}

Una parte significativa de los hogares de bajos ingresos que habitan en viviendas de áreas urbanas deficitarias de las periferias de muchas ciudades argentinas, utiliza su vivienda no sólo para habitar, sino también como lugar para emprender actividades económicas de tipos productivas, comerciales o de servicios, para venta de alimentos, frutas, verduras, para la preparación de comidas, para el funcionamiento de pequeños talleres de servicios mecánicos o manufactureros, para cría de animales, para huertas, entre otras actividades, haciendo de la unidad doméstica una unidad de reproducción y de producción a la vez.

Estas prácticas sociales tienen en parte relación con lo que la Organización Internacional del Trabajo (OIT) denomina "economía informal", aunque también tiene relación con lo que autores como Coraggio $^{6}$, desde una perspectiva más integral del desarrollo, denominan "economía popular", que es aquella economía no regida estrictamente por la lógica del capital, sino más centrada en la lógica

5 La economía informal incluye todas aquellas organizaciones económicas y de trabajo que se realizan al margen de las regulaciones del Estado y es una de las principales causas de la precariedad laboral y de la pobreza. Para una visión global de los debates sobre la definición, la teoría y las políticas sobre la economía informal consúltese la obra de Chen, 2012.

6

Coraggio, 2007, p. 163-194.

\section{Social Housing And Survival Skills}

An important segment of low-income households located in the deteriorated peri-urban areas of a large number of Argentinian cities use their housing units both as a dwelling and for the development of economic activities such as trade or the provision of goods and services. These activities also include; the sale of food, fruits and vegetables, the operation of small repair shops and manufacturers and the development of small-farming businesses, among others, thus turning the housing unit into a system of production and reproduction.

These social practices are associated with the concept of "informal economy" - developed by the International Labor Organization (ILO) ${ }^{5}-$ and the concept of "popular economy"-explored by authors such as Coraggio ${ }^{6}$, the latter being described as a type of economy that is not governed by the logic of capital but by the logic

5 Informal economy involves unregulated economic and work activities. This is one of the main causes of job insecurity and poverty. For further details on the definition, theory and policies on informal economy please refer to Chen (2012).

6 Coraggio, 2007, p. 163-194. 
del trabajo y en la reproducción simple de la vida, que dispone de reglas y arreglos no puramente capitalistas y cuya célula lo constituyen en gran parte las unidades domésticas, que tienen estrecha relación con el lugar de vida y con la vivienda ${ }^{7}$.

La persistencia de estas prácticas sociales muy extendidas radica en las características que asumen el trabajo y la integración social en la economía capitalista actual, en particular, en países donde la economía informal y la economía popular constituyen una parte significativa de la economía total. De acuerdo con Portes y otros autores de posiciones estructuralistas similares, el sector informal de la economía capitalista actual se encuentra íntimamente relacionada y subordinada al sector formal de la economía ${ }^{8}$. Esto permite explicar porque el crecimiento económico por sí mismo no necesariamente reduce la economía informal y es necesario que los gobiernos apliquen políticas activas para tal fin?.

Bertranou y Casanova ${ }^{10}$, que han realizado una investigación para la OIT sobre la informalidad laboral en la Argentina, sostienen que las políticas

7 En determinados contextos geográficos, como los del norte argentino, en el que persisten procesos migratorios de pobres rurales hacia las periferias urbanas, se observan en los barrios carenciados, prácticas de economía popular más centrada en la reproducción básica de la vida, que en la obtención directa de beneficios monetarios.

8 Portes y Haller, 2004, p. 11.

9 Bertranou y Casanova, 2013, p. 29-30.

10 Ibíd., p. 141-143.

22 revista invi № 84 / Agosto 2015 / Volumen № 30 19-57 of labor and the simple reproduction of life. Such a concept is somewhat detached from capitalrelated rules and conventions and is represented by the dwellings and their close relationship with the place of residence and the notion of housing.

These widespread social practices are based on the role played by labor and social integration in the current capitalist-based economy, most notably in countries where informal economy and popular economy have an important share of total economic activity. According to Portes and other authors who share a structuralist approach, the informal sector of the current capitalist economy is closely related and subordinate to formal economy. ${ }^{8}$ This allows us to explain why economic growth does not necessarily contribute to reduce informal economy and why governments are required to implement active mitigating policies. ${ }^{9}$

Bertranou and Casanova ${ }^{10}$ —who have recently conducted an ILO-commissioned research on

7 In some geographical contexts, such as in the case of northern Argentina - which concentrates migratory inflows from poor rural areas to peri-urban areas-, it is possible to identify popular economy practices focused on the basic reproduction of life rather than on income generation.

8 Portes and Haller, 2004, p. 11.

9 Bertranou and Casanova, 2013, p. 29-30.

10 Ibíd., p. 141-143. 
aplicadas en el país han generado una significativa reducción de la economía informal entre 2003 y 2012, no sólo por contener el crecimiento del empleo no registrado, sino también por crear puestos de trabajo de mayor calidad y este proceso también ha tenido como correlato mejoras en los indicadores de inclusión social y de distribución de ingresos. Aunque, a la vez, advierten que poco más del $30 \%$ de los trabajadores asalariados aún no se encuentra registrado en la seguridad social, mientras que esta cifra se ubicaría en el 58\% en el caso de los trabajadores independientes. Lo que significa que a pesar de los avances alcanzados en los últimos años, el empleo no registrado todavía está en niveles muy elevados.

Sin bien existen muchas actividades informales que trascienden el marco doméstico y se realizan fuera de las viviendas, en talleres clandestinos y en la calle, una parte importante de las mismas y en especial de la economía popular, se realiza en las viviendas de los sectores de bajos ingresos, porque existe una importante correlación entre el trabajo precario y el trabajo domiciliario, ya sea en relación de dependencia o de forma autónoma ${ }^{11}$.

Por otra parte, como se verá en los casos estudiados, existe una compleja y multidimensional relación entre formalidad e informalidad en la economía capitalista actual, por lo que algunos

11 Jelin, Mercado y Wyczykier, 1998, p. 1. labor informality in Argentina- suggest that policies pursued over the 2003-2012 period have considerably reduced informal economy. These measures, apart from containing the growth of informal labor, contributed to the creation of higher-quality jobs and improved the indicators of social inclusion and income distribution. However, it was revealed that 30 percent of paid workers are still not enrolled in the social security system; such a figure rises to 58 percent in the case of self-employed workers. This means that despite the achievements made over the last years, informal labor remains at very high levels.

While there is a large number of informal jobs that transcend the domestic sphere -illegal workshops, streets-, an important part of these activities -especially in the field of popular economy - is carried out in low-income dwellings. This is because there is a significant correlation between precarious and home-based jobs -independently if individuals are paid or self-employed workers. ${ }^{11}$

On the other hand there is a complex and multidimensional relationship between formal and informal aspects within the context of the current capitalist economy. This means that household members are involved in both spheres

11 Jelin, Mercado and Wyczykier, 1998, p. 1. 
integrantes de estos hogares tienen inserción en ambos sectores, ya sea porque disponen de algún trabajo registrado de baja remuneración o algún tipo de asistencia social y a la vez realizan actividades económicas domiciliarias, para la obtención de ingresos adicionales a los registrados. Por eso, pueden entenderse a estas prácticas como "estrategias de sobrevivencia". Según Cariola ${ }^{12}$, estas estrategias involucran el conjunto de prácticas que realizan los hogares destinadas a la obtención de ingresos para asegurar la reproducción material de la unidad doméstica. Al hacer referencias a ellas, Hintze prefiere hablar de "estrategias de reproducción" para hacer alusión a aquellas estrategias que (consiente o no conscientemente) desarrollan los hogares de los sectores populares urbanos para satisfacer sus necesidades y a través de las cuales:

"generan o seleccionan satisfactores para alcanzar sus fines reproductivos por medio de la combinación de las posibilidades a su alcance a través de un entramado de actividades que la relacionan con los demás agentes sociales" (De este modo) "las estrategias se configuran en el tiempo a través de sucesivos procesos en los que las unidades familiares establecen relaciones a distintos niveles: a) internamente (división familiar del trabajo, en términos sexuales y generacionales, entre actividades que producen ingresos y aquellos bienes por medio del trabajo doméstico); b) con otras unidades familiares; c) con el

12 Cariola, 1992.

24 revista invi No 84 / Agosto 2015 / Volumen N ${ }^{0} 30$ 19-57 of activity as they are engaged in formal lowpaying jobs — thus receiving social securityand carry out home-based activities in order to earn extra income. This is why these practices are known as "survival skills". According to Cariola", these skills are composed of the different practices developed by household members, which are intended to ensure the material reproduction of the housing unit. In this line Hintzeuses the term "reproduction strategies" to refer to those (consciously or unconsciously-driven) strategies that low-income households use to meet their needs; these tactics:

"Generate or select different satisfiers to achieve reproductive goals through the combination of possibilities within the context of the activities related to other social actors". (In this way) "strategies emerge through successive processes in which household units establish different relationships at different spheres, such as: a) internal (division of labor at household level according to gender, age and income-generating activities); b) multi-family; c) market-related; d) the civil society; and e) the State". ${ }^{13}$

However, ignoring the impact that these activities have, they are not recognized by the Argentinian

12 Cariola, 1992.

13 Hintze, 1989, 2004, p. 3. 
mercado; d) con otras instituciones de la sociedad civil y e) con el estado"13.

Sin embargo, ignorando el impacto que estas actividades tienen en la vida doméstica, la política habitacional argentina no las contempla como necesidades de estos hogares y asume de antemano que las viviendas serán usadas exclusivamente para habitar y no también en muchos casos para trabajar, menos aún en actividades que modifican de manera significativa el uso residencial y que afectan la habitabilidad en los sectores de bajos recursos que pretenden mejorar las políticas habitacionales.

Esta concepción de la vivienda como exclusiva para habitar fue masificada por el movimiento moderno de la arquitectura, a partir de aportes como los de Le Corbusier, adoptada luego en el mundo entero. Le Corbusier abogó por la separación de funciones entre el trabajar y el habitar como idea central para organizar las ciudades a partir de zonas funcionales. Este modelo de ciudad, promovió una estricta separación entre los espacios residenciales y los pertenecientes a las actividades económicas ${ }^{14}$ y fue adoptado histórico y acríticamente por la política habitacional argentina.

Es cierto que atendiendo a profundas críticas realizadas a muchos de aquellos planteos modernos

13 Hintze, 1989, 2004, p. 3.

14 Le Corbusier, 1986. housing policy system since housing is regarded as a unit intended exclusively for dwelling purposes. Home-based businesses and activities that significantly modify the housing unit are excluded as they may affect the habitability conditions of low-income areas included in housing policy programs.

This idea of housing as being exclusively to live in was put forward by the modernist movement in architecture, through the contributions of figures such as Le Corbusier, which later became adopted throughout the world.Le Corbusier championed the distinction between labor and dwelling as the model for the organization of cities into functional areas. Such a model, whichinvolved a strict separation between residential and business spaces ${ }^{14}$, was historically and uncritically adopted by the Argentinian housing policy system.

From the 90s onwards the Argentinian housing policy system, influenced by the deep criticism leveled by Lefebvre ${ }^{15}$ and Jacob ${ }^{16}$ against modern conceptions, revised aspects related to housing density, the size of housing developments, urban planning, the different forms of collective

\footnotetext{
14 Le Corbusier, 1986.

15 Lefebvre, 1971.

16 Jacob, 1973.
} 
por autores como Lefebvre ${ }^{15}$ o Jacobs ${ }^{16}$, a partir de los años 90s de la década pasada, la política habitacional argentina revisó aspectos relacionados con la densidad habitacional, el tamaño de los conjuntos habitacionales, el trazado urbano, las formas de viviendas colectivas y los estándares de calidad de las viviendas ${ }^{17}$, pero la concepción de la vivienda como ámbito exclusivo para habitar, continúa siendo aún hoy un paradigma sólido e incuestionable para ella, y esto a pesar de que partir del año 2003 la llamada "Política Federal de Vivienda" se orientó decididamente hacia a los sectores de bajos ingresos ${ }^{18}$.

El concepto de habitabilidad hace referencia a las cualidades que debe reunir una vivienda para ser habitable. Para Salas la habitabilidad básica, hace referencia al conjunto de equipamientos capaces de satisfacer las necesidades esenciales de habitar que tienen todas las personas. Estas necesidades requieren que se cubran las urgencias residenciales del vivir: no sólo las que conciernen al mero cobijo del hogar, sino también a los espacios públicos, infraestructuras y servicios elementales que constituyen, en conjunto, un asentamiento propicio para la reproducción vital ${ }^{19}$.

15 Lefebvre, 1971.

16 Jacobs, 1973.

17 Barreto y Alcalá, 2008.

18 Barreto, 2012

19 Salas, 2007. housing and the quality of dwellings. ${ }^{17}$ However, despite that housing policies began to focus on low-income segments with the so-called "Federal Housing Policy"18 _ implemented in 2003-, the concept of housing as a dwelling unit remains a strong and unquestionable paradigm.

The concept of habitability refers to the characteristics required by a dwelling in order to become suitable for habitation. According to Salas basic habitability is associated with a series of amenities that ensure the satisfaction of the basic habitation needs of people. These needs should be oriented towards the achievement of minimum living requirements;not only those that concern the shelter of the home, but also public space, infrastructure and the elemental services that provide the proper environment for vital reproduction. ${ }^{19}$

There is research that focuses on the quality and integrity of housing solutions aimed at lowincome segments and suggests the term "decent housing" as the goal that should be achieved by all housing policies. Such a notion refers to the concept of decent or adequate housing developed

17 Barreto and Alcalá, 2008.

18 Barreto, 2012.

19 Salas, 2007. 
Atendiendo a la calidad e integralidad de la soluciones habitacionales orientadas a los sectores de bajos recursos en Argentina, en otro trabajo se propuso el concepto de "hábitat digno" como meta a la que debe aspirar toda política habitacional. Este concepto incluye a la vivienda digna o adecuada formulada la por la $\mathrm{ONU}^{20}$ y reconocida en numerosas constituciones nacionales ${ }^{21}$, pero, pretende avanzar hacia una visión más integral del hábitat y la engloba junto a otros factores que en conjunto hacen un mínimo deseable nivel de calidad de vida de los hogares, en conformidad con la integralidad que demanda la interdependencia de los derechos humanos ${ }^{22}$. El mismo incluye a las condiciones habitacionales, pero incluye también condiciones para el ámbito barrial, su relación con la ciudad y los diversos factores que hacen a la integración de estos hogares a la sociedad: la tenencia segura de la vivienda, el acceso al trabajo decente y los recursos económicos necesarios para la reproducción adecuada de la vida, las protecciones sociales para acceder a la salud, la educación, la participación en la vida social y política, la identidad social

20 La ONU señala que para que una vivienda sea adecuada, debe reunir como mínimo los siguientes criterios: seguridad de la tenencia, disponibilidad de servicios, materiales, instalaciones e infraestructura, costo asequible, habitabilidad, accesibilidad, ubicación y adecuación cultural (ONU Hábitat, 2010).

21 La Constitución Nacional Argentina, expresa en los artículos 14 y 14 bis, el "derecho a una vivienda digna" y la "facultad de usar y disponer de ella".

22 Barreto, 2008. by the $U N^{20}$, which is recognized in different national constitutions. ${ }^{21}$ However, this concept is expected to offer a more comprehensive vision of habitat with the inclusion offactors associated with the provision of minimum quality of life standards at household level -in compliance with human rights standards. ${ }^{22}$ This concept, apart from including basic housing conditions, also involves neighborhood aspects, the relationship with the city and the different factors that create bonds between households and the society: secure tenure; access to decent work and the different economic resources required for an adequate reproduction of life; social security and access to healthcare and education; engagement in social life and politics; a positive social identity and different possibilities for the development of leisure and cultural activities, among others. ${ }^{23}$

The objective of this paper is to analyze, through a case study (focused on the neighborhood of Don Bosco, Resistencia, Argentina), the

20 The UN indicates that decent housing should meet the following minimum requirements: secure tenure, availability of services, materials, facilities and infrastructure, affordability, habitability, accessibility, location and cultural adaptation (UN, 2010).

21 Articles 14 and 14 bis of the Argentinean National Constitution refer to "the right to decent housing" and the "faculty to use and dispose of it".

22 Barreto, 2008

23 For further details on the concept of "decent habitat", please refer to Barreto, 2010. 
positiva y las posibilidades de disfrutar del ocio y la cultura, etc. ${ }^{23}$

A partir de todo lo señalado, el objetivo de este trabajo es analizar, mediante un estudio de caso (el barrio Don Bosco, Resistencia, Argentina) las adecuaciones entre las viviendas provistas por el Estado a sectores de bajos ingresos en el marco de la ayuda social y las actividades económicas de subsistencia que realiza un porcentaje importante de estos hogares, para arribar a algunos planteamientos conceptuales y a algunos lineamientos posibles a considerar en futuros programas habitacionales más integrales, que contribuyan al hábitat digno.

El estudio de campo se realizó entre junio y diciembre de 2013 en sucesivas visitas al barrio. La metodología empleada combinó el análisis de información primaria y secundaria.

La indagación teórica inicial permitió construir los observables de la investigación y a partir de ellos se elaboraron los instrumentos de registro y análisis de la información para estudiar las prácticas económicas de subsistencia que estos hogares realizan en las nuevas viviendas asignadas, con la finalidad de caracterizar el grado de afectación del uso residencial y la habitabilidad de la vivienda por parte de las mismas, con el objetivo de extraer modifications made to the social housing units provided by the State to low-income segments within the framework of social security and survival economy. This research is also intended to contribute conceptual approaches and guidelines for the development of comprehensive housing policies.

Field research was conducted between June and December, 2013, through different visits to the selected neighborhood. The methodology used by this paper combined the analysis of primary and secondary data. The initial theoretical research enabled the elaboration of the observable elements of this paper, which in turn served as the basis for the creation of recording and analysis instruments. These instruments were used for the study of the survival economy activities developed in the new housing units provided by the State and the effects of such a practice on the residential and habitability functions of dwellings. The goal is to draw conclusions and contribute to the provision of comprehensive solutions to the real needs of those involved.

Primary data was collected through participant and non-participant observations and semistructured interviews with a group of neighbors

23 Para un mayor desarrollo del concepto de "hábitat digno" ver Barreto, 2010. 
conclusiones que aporten a soluciones más integrales, adecuadas a las reales necesidades de los destinatarios.

La información primaria se recabó mediante observaciones no participantes, participantes, y entrevistas semi estructuradas a un grupo de vecinos residentes en el barrio Don Bosco, seleccionado a partir una muestra no probabilística (intencional) construida con criterio de significatividad etnográfica y diversidad en las actividades productivas ${ }^{24}$. En las observaciones no participantes, se registraron los tipos de actividades económicas desarrolladas en las viviendas; los espacios de las viviendas donde ellas se realizaban (pudiendo ser en el interior de la vivienda, en el exterior dentro del lote o en el espacio público); la cantidad y modo en que los locales o espacios fueron afectados por estas actividades; el grado de impacto y adecuación de estas actividades en relación al uso residencial de las viviendas; las modificaciones realizadas para emprender estas actividades y el impacto de las mismas en las viviendas vecinas.

En las entrevistas se profundizó acerca de la cantidad de personas del hogar que trabajaban y que tipo de trabajo realizaban; se preguntó si

24 En la primera instancia de observación se detectaron veinte hogares (de setenta y ocho) que realizaban actividades económicas en las viviendas y de ellos se seleccionaron con estos criterios cuatro para las entrevistas en profundidad. from Don Bosco; this group was selected on the basis of a non-probabilistic sample developed according to ethnographic elements and the diversity of productive activities. ${ }^{24}$ Nonparticipant observations involved the recording of the different types of home-based economic activities; the spaces where these activities take place (at home, in the area outside the house or in the public space); the number and extent to which these spaces are affected by such activities; the impact and degree of adaptation of these activities in relation to the residential function of dwellings; the modifications made to conduct these economic activities and the effects of such activities on neighboring dwellings.

The interviews conducted during this research explored the number of household members who are engaged in labor activities and the kind of work they perform. Respondents were also asked about the comfort level of their dwellings in relation to the residential function of housing and the home-based activities they performed; what features of their dwellings they would like to change and how they would like their housing to look; how and where they develop their

24 The first observation stage of this research showed that 20 out of 78 households developed home-based economic activities. Four of these 20 households were selected for further in-depth interviews. 
les resultaba cómoda la vivienda para vivir y trabajar; qué cambiarían de la vivienda y cómo les gustaría que fuera; dónde y cómo desarrollaban sus actividades; cuántos ambientes utilizaban para trabajar; qué creían que necesitaban en la vivienda para llevar a cabo las actividades; dónde desarrollaban las actividades restantes; cómo se relacionaban con los vecinos en función de sus actividades, etc.

En estas indagaciones se trató de captar los sentidos que las personas le otorgaban a sus prácticas y experiencias y fueron complementadas con el registro grafico de las condiciones de vida y habitacionales de los hogares. Para el procesamiento de la información se ha empleado la técnica de análisis de contenido del discurso, extrayendo de las entrevistas los aspectos más significativos sobre las prácticas de subsistencia y las necesidades de adecuación de la vivienda a estos fines.

La información secundaria analizada comprendió los documentos del programa habitacional y documentos gráficos del proyecto urbano y de las viviendas. De ellos se consideraron las características normativas del programa, las posibilidades de crecimiento de las viviendas y la información que el programa proveyó a los destinatarios para ampliar o modificar sus viviendas. Para la interpretación del registro gráfico se ha implementado la técnica de análisis espacial. activities; how many spaces they use for labor purposes; the items they need to perform their activities; the places where they develop other type of activities; and the relationship with their neighbors within the context of the activities they perform, among others.

This research seeks to interpret the meanings given by respondents to their practices and experiences; the results of such an exercise are complemented with graphic depictions of the living and housing conditions of dwellings. As for data processing this paper uses the discourse analysis technique, which is based on the summary of the most important aspects mentioned during the interviews - such as those related to survival skills and the subsequent modification of the housing unit.

The analysis of secondary data involved the review of the housing program and graphic documents related to urban projects and housing units. Such an analysis considered the regulatorycharacteristics of this program, the possibilities for the enhancement of dwellings and the information provided to users in relation to the expansion and modification of housing units. The interpretation of graphic data was conducted through the use spatial analysis methods. 


\section{El estudio de caso: el barrio Don Bosco (Resistencia, Chaco)}

El Barrio Don Bosco está ubicado en el borde noreste de la Ciudad de Resistencia, provincia del Chaco (Argentina) en cercanías al cauce del Río Negro (figura 1), dentro de un área ambiental compuesta por lagunas y meandros que se caracteriza por una fuerte fragmentación social dada por la cercanía de barrios de distintos estratos. En esta área existe un importante porcentaje de población de bajos ingresos que habitan en asentamientos informales, pero también hay barrios públicos de viviendas y barrios tradicionales de clase media, así como algunos barrios de clase media alta, con muy baja interacción entre todos ellos.

Don Bosco es uno de los asentamientos informales del área, del cual un grupo de hogares debió ser relocalizado parcialmente dentro del mismo barrio a raíz de obras de drenaje y saneamiento que se están realizando en el área. Con este fin se está construyendo en cercanías un conjunto habitacional nuevo en el marco del Programa de Prevención de Inundaciones y Drenajes Urbanos (PIDU). Este Programa se encuentra realizando obras estructurales en el área para prevenir y mitigar el daño causado por inundaciones. El PIDU desarrolla medidas estructurales y no estructurales, las primeras relacionadas con el drenaje urbano y periurbano, las cuales

\section{Case Study: The Neighborhood of Don Bosco (Resistencia, Chaco)}

Don Bosco is located in the northeast area of the city of Resistencia, Chaco Province (Argentina), near Rio Negro (figure 1). This is an environmental area composed of lakes and meanders and is characterized by a strong social fragmentation, which is generated by the proximity of neighborhoods of different social strata. There is an important percentage of low-income population who live in informal settlements; however, this area also includes public neighborhoods, traditional middleclass neighborhoods and upper middle-class neighborhoods. There is almost no contact among these zones.

Don Bosco is an informal settlement that had some ofits houses relocated as the result of draining and cleaning works in the area. These projects are part of the construction of a housing development within the context of the Urban Flood Prevention and Drainage Project (UFPDP). Such an initiative is promoting the implementation of structural works within the area in order to prevent and mitigate flooding hazards. The UFPDP is in charge of implementing structural 
han implicado el desplazamiento obligatorio de población para la construcción de las obras y dentro de las segundas, se está ejecutando un subprograma de vivienda que está construyendo el conjunto habitacional del barrio Don Bosco. Este subprograma tiene como objetivo servir de solución para el reasentamiento obligatorio de los hogares informales asentados en los terrenos necesarios para la construcción y operación de las obras estructurales y también para reasentar, en forma voluntaria, a los hogares asentados en zonas de riesgo hídrico dentro de la cuenca de las obras estructurales. Estas obras son realizadas con el financiamiento del Banco Mundial y el organismo provincial a cargo es la Sub Unidad de Obras y Programas Especiales (SUOPE) del gobierno de la Provincia del Chaco.

El plan habitacional prevé la construcción de 207 viviendas mínimas individuales para hogares de 4 o 5 integrantes ubicadas en lotes de 9x18 m, de las cuales 78 fueron asignadas a inicios del año 2013 y las restantes 129 se culminarán durante el 2014. Los prototipos de las unidades de vivienda fueron de uno, dos y tres dormitorios, de acuerdo a la composición familiar, determinada por el censo realizado oportunamente por el Programa. Cuentan con cocina-comedor, baño, lavadero y un hall exterior de acceso demarcado por una pérgola. El techo de cada vivienda tiene una sola pendiente para que las viviendas de uno y dos dormitorios puedan crecer hacia atrás hasta alcanzar el modelo de tres dormitorios (figura 2). Las viviendas fueron and non-structural measures. In this sense, while the former measures are related to urban and peri-urban drainage issues —which involved the forced displacement of people for the development of improvement works-, the latter initiatives are associated with the implementation of the housing sub-program in charge of the construction of a housing development in Don Bosco. The aim of this sub-program is to resettle those informal settlements located in lands suitable for the construction and operation of structural works and offer an optional resettlement to those households located in areas prone to waterrelated hazards. The World Bank funds these projects and the provincial body in charge of managing these programs is the Subcommittee on Projects and Special Programs (SPSP) at the Chaco Province Government.

This housing project involved the construction of 207 basic housing units, which were built over an area of 9x18 meters intended for families up to 4-5 members.Seventy-eight of these dwellings were delivered in 2013 and the remaining 129 units in 2014. These dwellings are available in one, two or three bedroom options according to the composition of families, which was determined by a census conducted by this housing Program. All units are equipped with a living/dining room, a bathroom, a washing place 
FIGURA 1. LOCALIZACIÓN DEL NUEVO CONJUNTO HABITACIONAL DEL BARRIO DON BOSCO FIGURE 1. LOCATION OF THE NEW HOUSING COMPLEX IN DON BOSCO

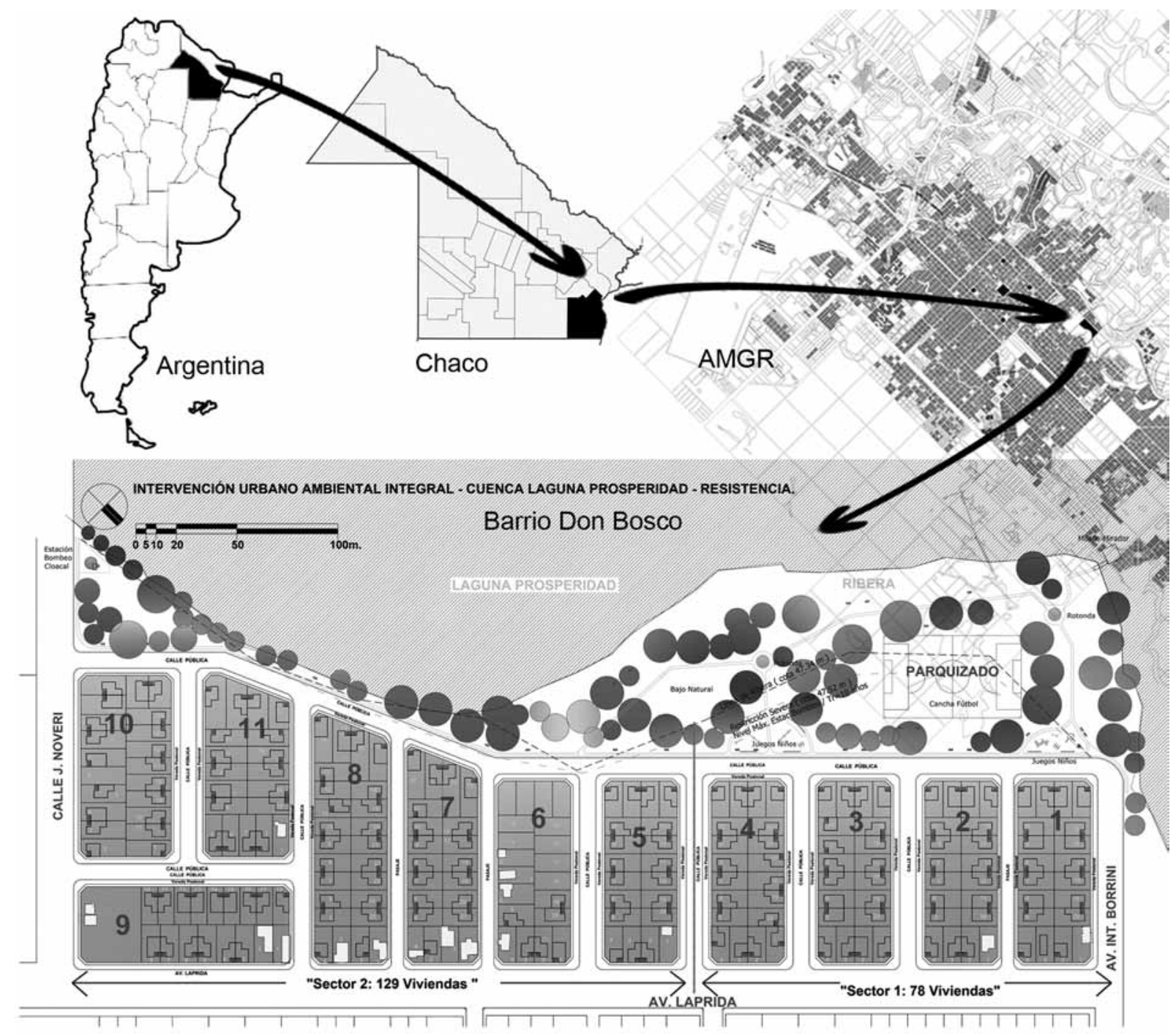

Fuente: Elaboración propia en base a SUOPE.

Source: Elaborated by the authors based on data retrieved from the SPSP 
FIGURA 2. AMPLIACIÓN DE NÚMEROS DE DORMITORIOS PREVISTA PARA LOS PROTOTIPOS DE UNO Y DOS DORMITORIOS

FIGURE 2: EXPANSION IN THE NUMBER OF BEDROOMS ALLOWED FOR ONE AND TWO BEDROOM DWELLINGS

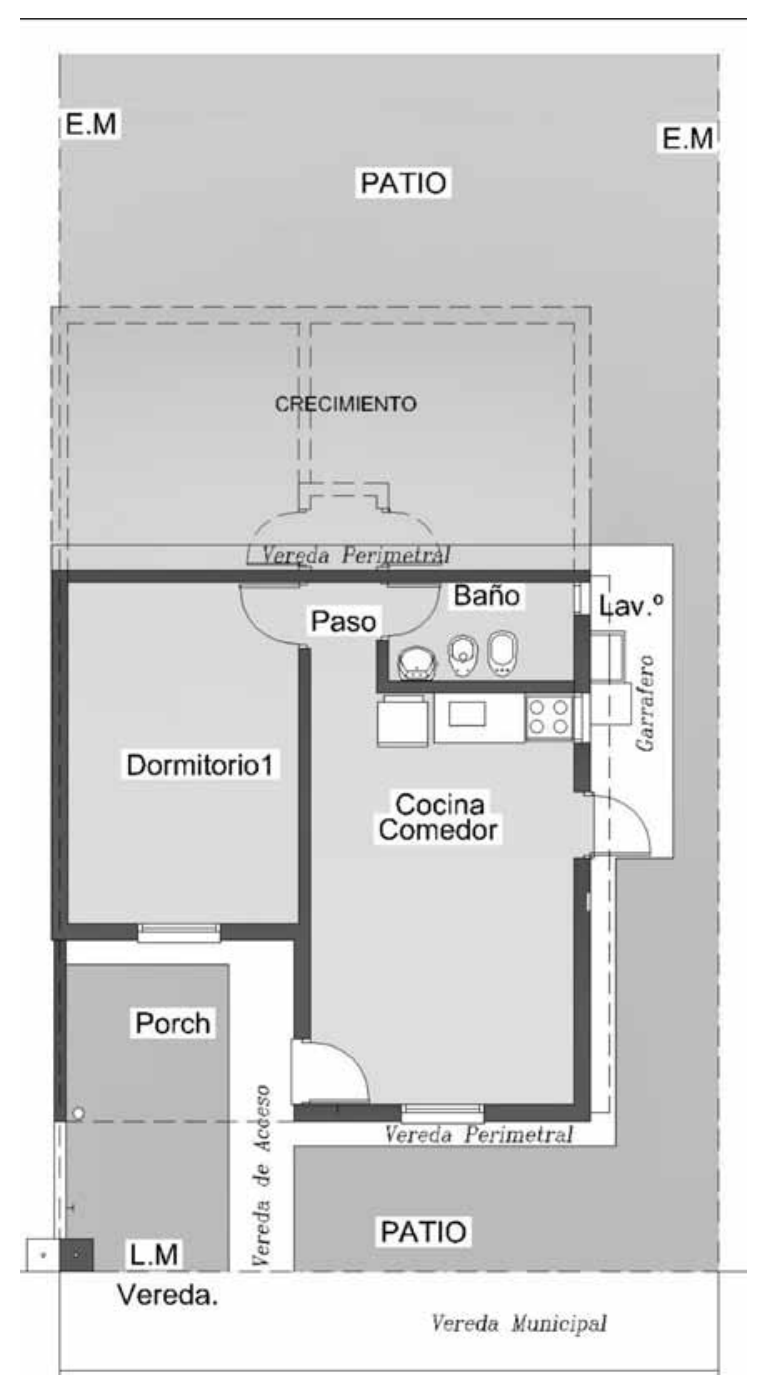

Fuente: SUOPE.

Source: SPSP 
construidas de ladrillos a la vista, techos de chapa, carpinterías de madera y cuentan con los servicios básicos de agua potable, electricidad y desagües cloacales, las calles son de tierra, con desagües pluviales a cielo abierto y las veredas cuentan con una senda peatonal de $60 \mathrm{~cm}$. Si bien el diseño de las viviendas admite el crecimiento cuantitativo de dormitorios, no previó cambios cualitativos respecto a la funcionalidad de las mismas.

\section{El impacto de las actividades de sobrevivencia en las viviendas analizadas}

En el barrio Don Bosco inaugurado parcialmente a inicio del 2013, son numerosas las familias que usan la vivienda para el desarrollo de actividades económicas de sobrevivencia superpuestas a las actividades de residencia, de las 78 viviendas asignadas en la primera etapa, en alrededor de 20 de ellas se registraron estas actividades. En las mismas, se desarrollan distintos tipos de actividades, entre ellas: crías y cuidado de animales de trabajo, talleres de diferentes servicios mecánicos, carpinterías, ferreterías, comercios de alimentos, ventas de frutas y verduras, modistas, peluquerías, rotisería ${ }^{25}$, etc., en general de carácter informales, es

25 En Argentina la rotisería es un comercio que vende comidas para llevar, especialmente asados, quesos y fiambres. and an outer hall. Each of these dwellings has a mono-pitched roof in order to make it possible for one and twobedroom homes to evolve into a three-bedroom dwelling (figure 2). These units were built of exposed brick and wood, equipped with sheet-metal roofs and basic services such as drinking water, electricity and sewage systems. As for public spaces, there are unpaved roads with open storm water drainage systems and sidewalks are $60 \mathrm{~cm}$ wide. However, while the design of these units enabledthe expansion of dwellings in quantitative terms, there were no qualitative considerations as for the function of these new spaces.

\section{The Impact of Survival Activities on Dwellings}

Partially launched in 2013, the social housing complex located in Don Boscohas been used both for residential use and for the development of survival economic activities. Such a duality has been identified in 20 out of the first 78 units delivered by the State. These home-based activities include the operation of small-farming businesses, repair shops, carpentry services, 
decir, no registradas, ni reguladas por el municipio, que generan diferentes grados de impactos en el uso residencial de las propias viviendas y de las viviendas vecinas:

- En el caso de las actividades de comercialización de productos alimenticios, las modificaciones introducidas por los moradores van desde el simple cambio de funciones de algún ambiente de las viviendas originales, que generalmente afectan al estar-comedor o también puede afectar a un dormitorio, hasta la ampliación de algunos de ellos o la construcción de un nuevo local para tal fin. En todos estos casos y generalmente por razones de seguridad o por falta de espacio, es habitual que los consumidores no ingresen a las viviendas, sino que sean atendidos desde el exterior a través de una ventana o una puerta. En algunos casos, como las ventas de frutas y verduras, suelen sacarse diariamente los cajones al frente de las viviendas para ser exhibidos en el exterior, en algunos casos colocados sobre exhibidores rudimentarios. Estas actividades en general afectan la comodidad o el confort del uso de la vivienda para la vida residencial y tienen bajo impacto en el uso residencial de las viviendas vecinas o de los espacios hardware stores, food trade, sale of fruits and vegetables, seamstressing, hairdressing salons and delicatessens ${ }^{25}$, among others. Such activities are informal in nature, since they are not registered, nor are they regulated by the municipality and affect in varying degrees the residential function of the host and neighboring dwellings:

- In the case of the trade of food, modifications range from the alteration of one of the spaces of the dwelling - most notably the living/dining room and bedrooms - to the expansion and construction of a dedicated physical space. In each of these cases, and mostly owing to lack of space or safety reasons, consumers do not enter into the dwelling and are attended to either through a window or a door. Occasionally, as in the case of the sale of fruits and vegetables, all products are displayed outside the housing unit. These activities affect the comfort level of dwellings and have almost no effects on neighboring houses and public spaces. However, sidewalks are sometimes blocked by these products (figure 3).

- Work animals, mostly horses —which are generally used to pull loading carriages, collect

25 In Argentina, delicatessen shops sell takeaway food, especially roasted food, cheeses and cold cuts. 
públicos del barrio, aunque en algunos casos pueden obstaculizar las sendas peatonales de las veredas (figura 3).

- En los casos del cuidado de animales de trabajo, como son los caballos, generalmente utilizados en carros de cargas, empleados para la recolección y reciclado de residuos urbanos, o para realizar servicios de fletes, o para trabajar en las ladrillerías artesanales ubicadas en la zona costera del río o simplemente para traslado, el ambiente utilizado es el exterior de la vivienda, generalmente el patio, al cual se le practica cerramientos con muros de ladrillos o con empalizadas precarias, en algunas ocasiones se construyen algún cobertizo o pequeño galpón precario anexo a la vivienda. Estas actividades en general tienen mayor impacto en el uso residencial de las propias viviendas y de las viviendas vecinas o también de los espacios públicos del barrio, por los malos olores que puede generar la acumulación de desechos animales o de residuos, en el patio de las viviendas o en el frente de las mismas (figura 3).

- En el caso de los talleres de servicios para el arreglo de motos y bicicletas o las carpinterías, generalmente se procede al techado precario de una parte o a veces de todo el patio de la vivienda. Estas actividades en general tienen también impacto en el uso residencial interior de la propia vivienda, así como en las viviendas vecinas and recycle urban waste, provide freighting services, at the handmade brickworks or simply as a mean of transportation-, are bred in the area outside the housing unit, most notably in courtyards. Such a space is turned into an enclosure made of precarious brick walls or fences. In some occasions, huts or small sheds are poorly constructed next to the housing unit. These activities have a greater impact on the residential use of host and neighboring dwellings and public spaces due to the strong odor generated by the animal waste and residuesleft in courtyards or in front of the buildings (figure 3).

- In the case of motorbike or bicycle repair shops or carpentry services, courtyards are partially or completely covered over with precarious roofs. These activities have an important impact on the residential use of host and neighboring dwellings and public spaces due to noise and gas emissions and obstruction of the sidewalk. In some cases, the presence of the abovementioned roofs reduces natural illumination and ventilation, thus affecting the comfort level of dwellings.

There follows four different cases intended illustrate and to expand on this analysis: 


\section{FIGURA 3. IMÁGENES ILUSTRATIVAS DE ALGUNAS ACTIVIDADES PRODUCTIVAS REALIZADAS EN LAS}

\section{VIVIENDAS}

\section{FIGURE 3. PICTURES OF SOME HOME-BASED PRODUCTIVE ACTIVITIES}
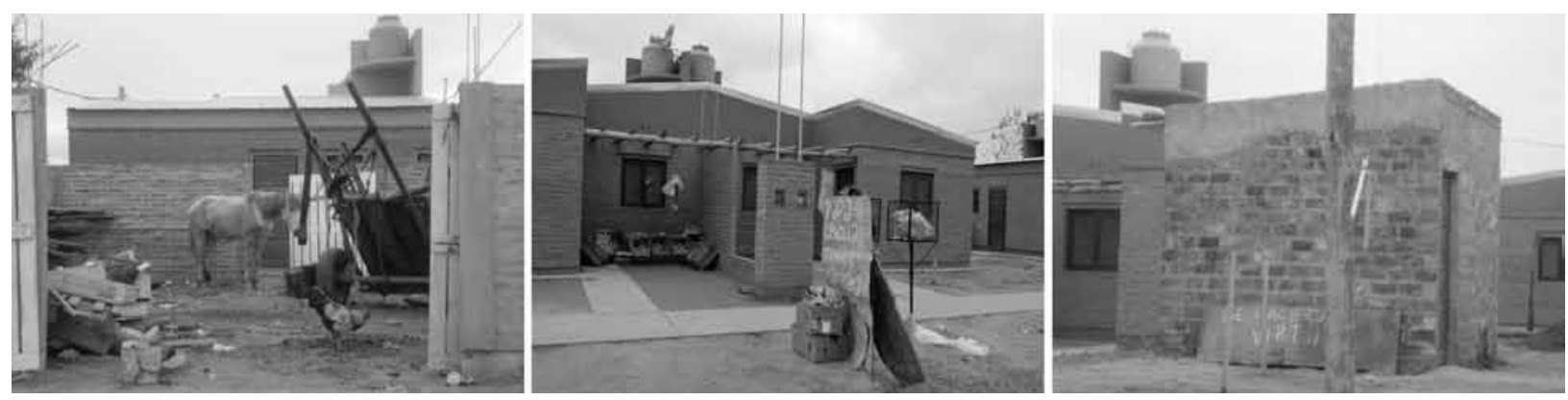

Fuente: Elaboración propia.

Source: Elaborated by the authors

y en los espacios públicos del barrio, por ruidos molestos, combustión de gases en el patio de las viviendas o porque obstaculizan las sendas peatonales de las veredas. En oportunidades el techado del patio disminuye la iluminación y ventilación natural de las viviendas y por ende afecta el confort del uso residencial de la vivienda.

A continuación se exponen cuatro casos diferentes para ilustrar más en detalle los análisis realizados:

\section{UNA ROTISERÍA}

Se trata de una familia que desarrolló una rotisería en la nueva vivienda. Inmediatamente que ésta les

\section{A DELICATESSEN BUSINESS}

This is the case of a family that established a home-based delicatessen business. Upon receiving the new dwelling, this family saw an opportunity to embark on a micro-business venture. The idea was to continue in the line of business in which the father of the family had workedfor over 30 years in different restaurants in the city, but this time for himself. A veteran from thewar in the South Atlantic (1982), this householder is in receipt of a State pension and performs this new activity in order to augment formal household income. 
fuera adjudicada, ellos la vieron como un medio para llevar a cabo su propio micro emprendimiento, a partir de dar continuidad, pero por cuenta propia, a una larga trayectoria familiar en el rubro, ya que el padre de familia había trabajado durante 30 años en distintos restaurantes de la ciudad, pero siempre en relación de dependencia. Este padre de familia recibe una pensión del Estado en carácter de soldado ex combatiente de la guerra de las Islas Malvinas (1982) y realiza esta actividad como un complemento de los ingresos formales del hogar.

$\mathrm{Al}$ principio las modificaciones fueron solo funcionales, iniciaron sus actividades con la venta de frutas y verduras en el espacio libre frente a la vivienda (destinado en el proyecto original a futuro garaje) y a la cocción de alimentos en el estar-cocina-comedor. Entre ambas actividades ocuparon casi la totalidad del único espacio social con el que cuenta la vivienda. A los pocos meses optaron por tener sólo la rotisería e introdujeron modificaciones constructivas para ampliar la vivienda mediante la construcción de un pequeño local en el hall de acceso (figura 4). Esto implicó dejar sin ventana una de las habitaciones de la vivienda, con la consecuencia de afectación de la ventilación e iluminación natural de ese dormitorio. Esta familia tiene la intención de seguir ampliando este local hasta la línea municipal, para disponer de más espacio para tal fin. De este modo lo explicó el padre de la familia:
At the beginning, the new dwelling underwent functional alterations and the family began selling fruits and vegetables in the unoccupied space of the housing unit -which was originally intended for a garage- and offering cooking services in both the kitchen and the living/dining room. This meant that most of the intended social area of the dwelling was required to run these two businesses. A few months later the family decided to set up a delicatessen business and expanded the housing unit by building a small store in the access hall (figure 4). As a result one of the bedrooms was left without a window, thus generating ventilation and illumination issues. This family intends to continue expanding this store until reaching the municipal limit. As the householder explained:

“... We had a thought when we visited this dwelling, we said lets set up a food business and we made it happen..."

“... Before we used to do everything in the dining room; we cooked, sold and we had our vegetables outside the house but later we decided to expand the store. We closed the outer hall and left a space for a window. I always worked in restaurants, for 30 years, but I'm tired of working for employers and said that one day I would have my own business..." 


\section{FIGURA 4. IMPACTO DE LA ROTISERÍA EN EL USO RESIDENCIAL}

FIGURE 4. THE IMPACT OF THE DELICATESSEN BUSINESS ON RESIDENTIAL FUNCTIONS

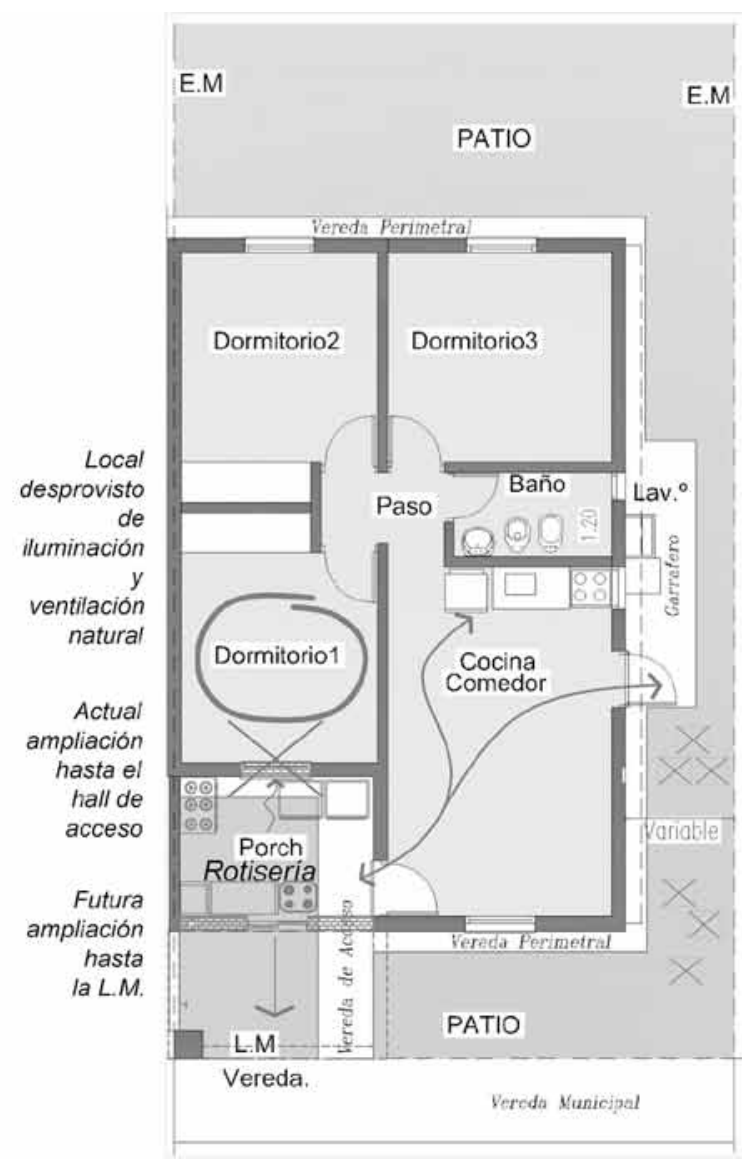

Fuente: Elaboración propia.

Source: Elaborated by the authors
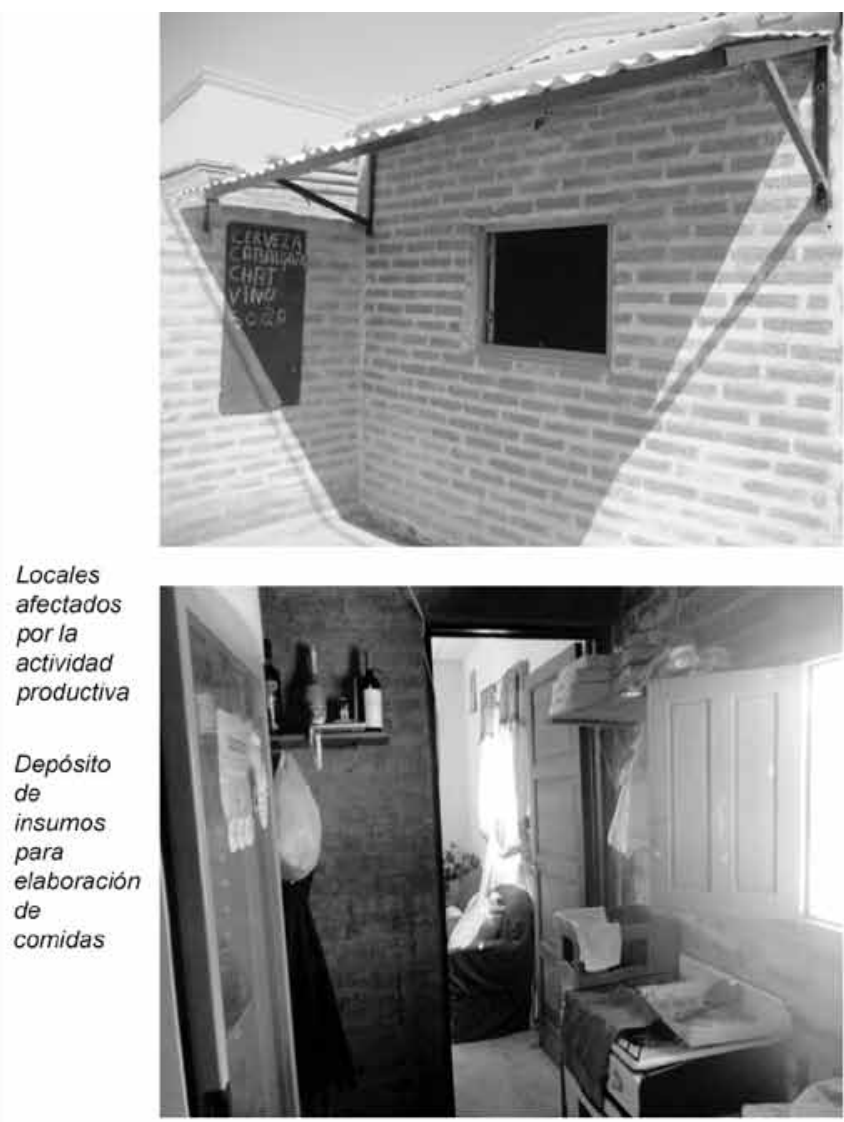

ARTICLE: Social housing and survival skills.appropriate solutions provided by a case study (Resistencia, Argentina, 2013) / Miguel Ángel Barreto, María Andrea Benítez, María Laura Punte 
“...Nosotros teníamos un pensamiento cuando veníamos a ver la vivienda, dijimos vamos a poner un local de comida y lo hicimos realidad..."

“...Antes hacíamos todo en el comedor, cocinábamos y vendíamos y teníamos la verdulería afuera, pero después ampliamos. Donde estaba la pérgola cerramos y pusimos la ventana. Siempre trabajé en restaurantes, 30 años, y ya me canse de trabajar para los patrones y dije un día voy a tener mi lugar de trabajo..."

"Querríamos ampliar un poquito porque vio que tengo archivaditas las cosas ahí, igual nos arreglamos pero es muy chico, me gustaría ampliar..."

\section{UN COMERCIO DE ALIMENTOS}

En este caso se trata de una familia que, desde antes que se le adjudicara la vivienda, ya tenía un local comercial de este tipo en su anterior y precario lugar de residencia. A este grupo familiar se le adjudicó una vivienda de tres dormitorios ubicado en un terreno de una esquina de manzana, de modo que pudieron ubicar el local en uno de los dormitorios que da hacia la calle lateral de la vivienda y solamente tuvieron que abrir una ventana para vincular ese dormitorio con la calle, también colocaron un toldo y construyeron algunos escalones para que los clientes pudiesen alcanzar el nivel de la ventana y estuviesen protegidos de la intemperie mientras realizan las compras (figura 5). Entre las mayores preocupaciones de esta familia se encuentra la necesidad de independizar
"We would like to extend a little bit because I have my files there; anyway, we manage ourselves to work in this space but it is very small, I would like to extend this house..."

\section{A FOOD TRADE BUSINESS}

This is the case of a family that had already runa home-based business in a precarious place of residence prior to moving into these new housing units. This family was provided with a three-bedroom dwelling located in the corner of a street, which allowed them to concentrate onthe development of a business in a single bedroom. The only thing they had to do was to open the window of this bedroom - which is oriented towards a side street-, install an awning and build some steps in order to allow customers to reach this window and protect them against weather while making their purchases (see figure 5). The major concern for this family is associated with the need to divide labor and residential functions, since such a business involves the participation of the living/dining room and the kitchen. As the householder says:

“... We are using one of the bedrooms and there is no problem with that, the issue is that at the moment I have to take everything through here (living room), I want to take out the window and put a door there in the corner 


\section{FIGURA 5. IMPACTO DEL COMERCIO DE ALIMENTO EN EL USO RESIDENCIAL FIGURE 5. THE IMPACT OF FOOD TRADE ON RESIDENTIAL FUNCTIONS}
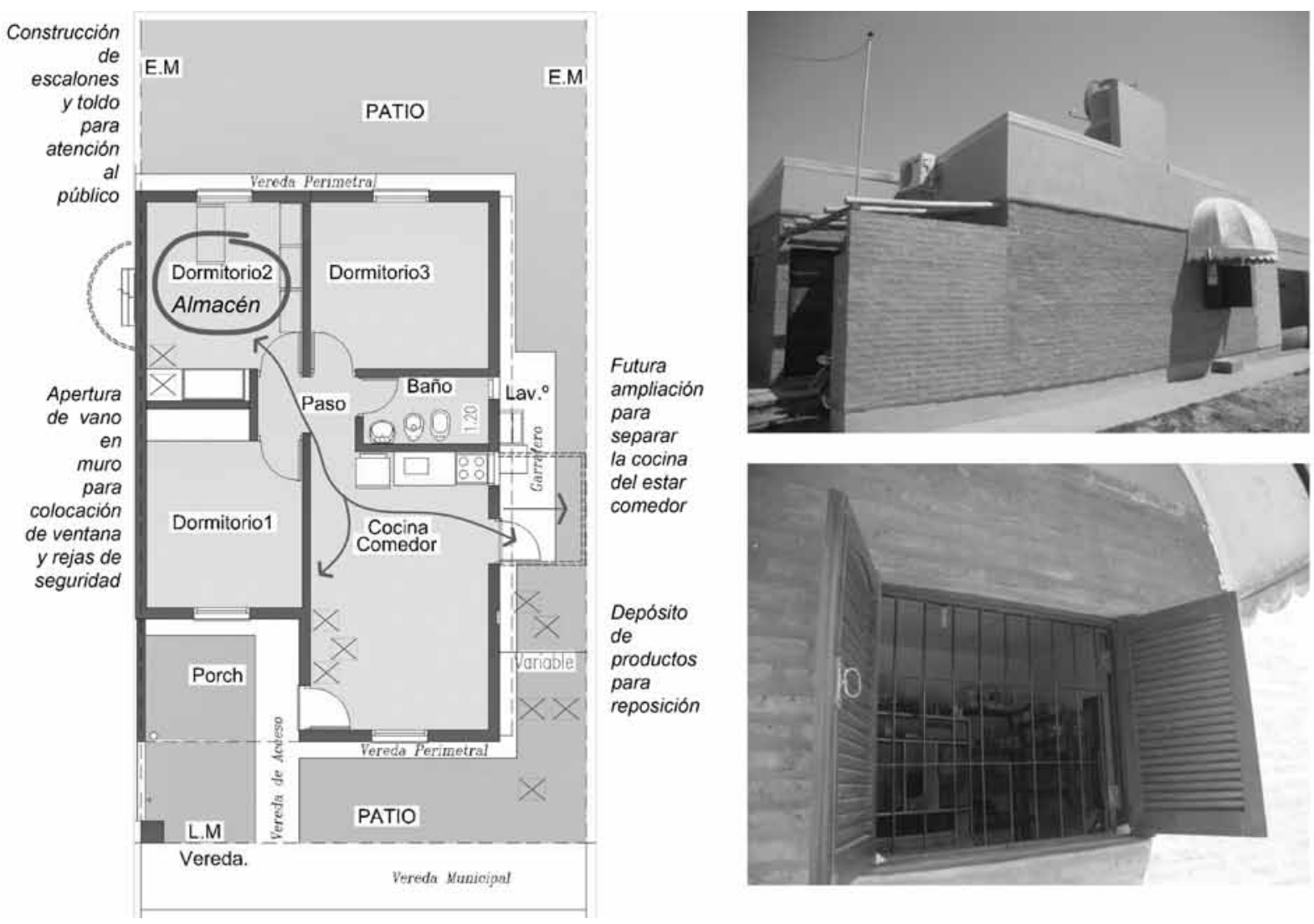

Fuente: Elaboración propia.

Source: Elaborated by the authors 
las funciones laborales de las residenciales, debido que para abastecer de mercaderías el dormitorio debe pasar por el estar-comedor-cocina. Según la madre de familia:

“...Estamos usando una de las habitaciones, no tengo problemas, pasa que por ahora tengo que pasar todo por acá (living), quiero sacar la ventana esa y poner una puerta ahí en la esquina y entonces me manejo por la puerta con el negocio..."

“...No puedo hacerle más cambios porque no tengo donde, yo ahora tengo todos desarmados los cajones o sino quiero guardarlo acá (living) pero no puedo porque tengo la moto, pero no me queda lugar porque yo con el tiempo, quiero cerrar esto y llevar allá la cocina y dejar acá que sea living comedor..."

En este caso fue interesante observar la racionalidad dada al uso de la vivienda por la jefa del hogar y las ideas que tiene para independizar las funciones comercial y residencial en pos de un mayor confort en el uso de la vivienda, capitalizando la ventaja dada por la ubicación en esquina de la misma.

\section{UN TALLER DE MOTOS Y BICICLETAS}

En este caso, se trata de una familia, cuyo jefe de hogar aprendió por sí mismo la habilidad de reparar motos y bicicletas. En los últimos años se dio un crecimiento acelerado del uso de motos porque muchos de los hogares de los sectores populares han accedido a ellas y las utilizan diariamente para trasladarse, por consiguiente, ha ido creciendo la and then I would manage everything through the door of the shop ..."

“... I cannot make more modifications because there is no more room, all the drawers are dismantled and I cannot move these items to the living room as my motorcycle is there, I have no more space; I would like to close this area and relocate both the kitchen and the living/dining room..."

It isinteresting tonote the rationalitybehind the use of the dwelling on the part of the householder and the ideas they have to separate both economic and residential functions; such a division is intended to increase comfort levels and take advantage of the physical location of the housing unit.

\section{A MOTORBIKE AND BICYCLE REPAIR SHOP}

This is the case of a family whose self-trained householder repairs motorcycles and bikes. There has been a steep increase in the use of motorcycles over the last yearsas this mean of transportation has become more accessible to low-income users. This led to the emergence of a series of informal repair shops. In this case the main modification underwent by the housingunitwasthe construction of a roof over a section of the courtyard, even though the whole space is needed to perform such an activity. Likewise the washing place was 


\section{FIGURA 6. IMPACTO DEL TALLER DE MOTOS Y BICICLETAS EN EL USO RESIDENCIAL FIGURE 6. THE IMPACT OF THE REPAIR SHOP ON RESIDENTIAL FUNCTIONS}

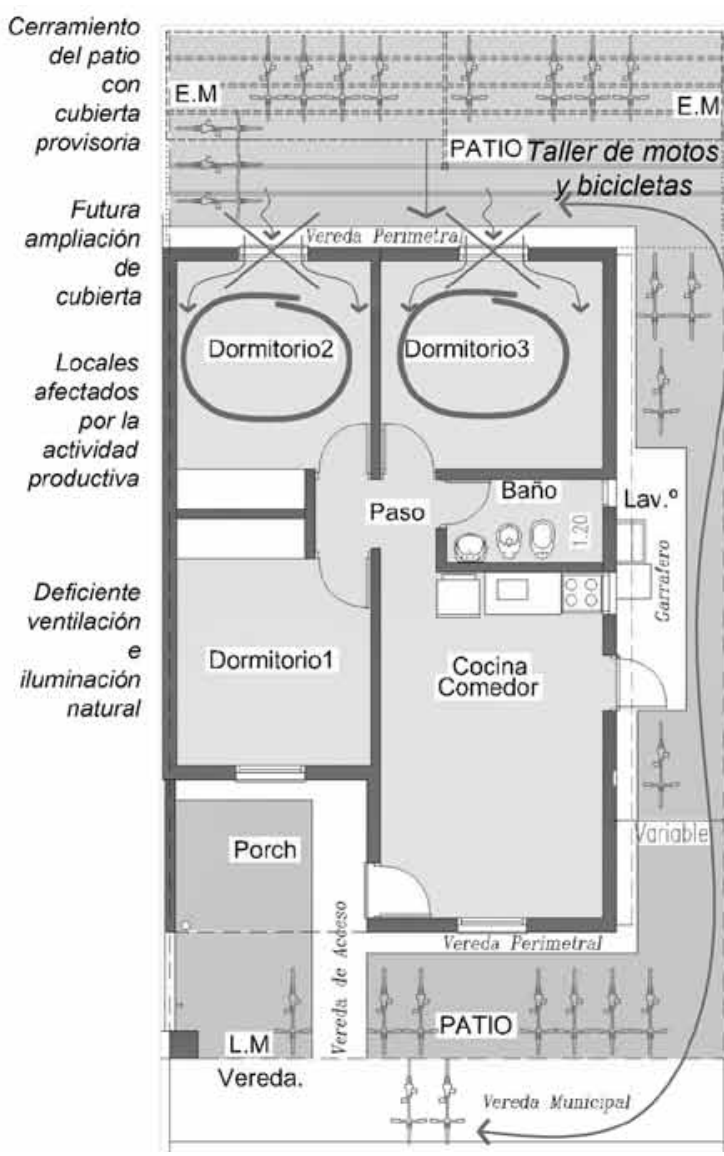

Fuente: Elaboración propia.

Source: Elaborated by the authors

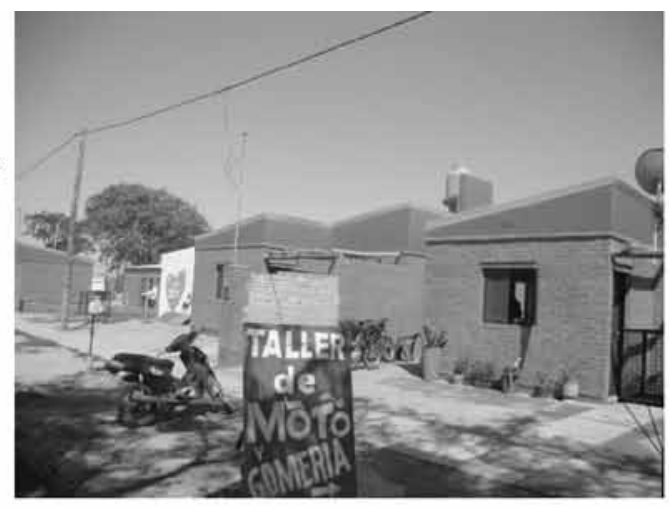

Locales

afectados

porla

actividad

productiva

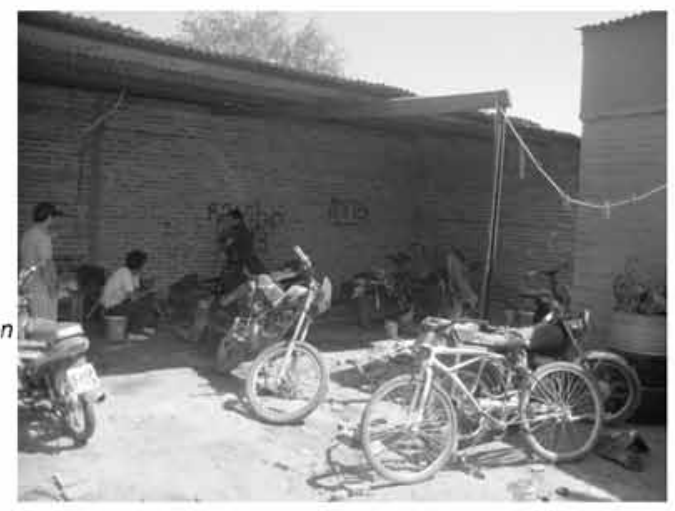

Obstaculizacior

de la

circulación

principal

en la via

publica 
aparición de lugares informales que brindan servicios de mantenimiento y arreglo de estos vehículos. En este caso, la principal modificación introducida consistió en el techado de una parte del patio, aunque para la actividad prácticamente se ocupó todo el patio. Así como también se diversificaron las funciones en el lavadero, utilizado como mesa de trabajo del taller, sin las debidas instalaciones para depurar combustibles. El padre de familia señaló:

"...Para trabajar usamos desde la entrada del costado hasta el fondo, estamos ampliando, techamos para guardar las motos..."

En este caso las partes más afectada del uso residencial de la vivienda han sido el patio y el lavadero y de continuar la ampliación también tendrá consecuencias en el confort interior, ya que podría afectar la iluminación y ventilación natural de la vivienda (figura 6).

\section{UN QUIOSCO}

En este último caso se trata de una familia que tuvo que modificar parte de su trayectoria laboral. Previamente, cuando vivían de forma semirural en un valle de inundación de la zona, se dedicaban a la cría de caballos para acarreo de fletes y tenían un quiosco. Actualmente, debido a las restricciones que le puso el Programa para adjudicarles la vivienda, debieron abandonar el servicio de fletes, aunque continúan teniendo animales en otro sitio turned into a work table that is not suitable for fuel treatment. In the words of the householder:

“... In order to perform our activity, we use an area covering from the side entrance to the back of the house, we are extending this dwelling, and we constructed this roof to park motorcycles..."

In this case, the most affected areas of the housing unit are the courtyard, the washing place and, in the event of expansion, the comfort level of the dwelling since natural illumination and ventilation may be altered by the development of such a home-based activity (figure 6).

\section{A KIOSK}

This last case refers to household members that were forced to modify their occupational lives. Prior to their arrival in Don Bosco, this family lived in a semi-rural way in an alluvial valley where they were involved in breeding horses for freight haulage and had a kioskand a freighting business. Today, as the result of the restrictions imposed by the Program which grants housing, they had to abandon their freight business. However they breed their animals in other area, for which they pay a monthly lease, and have set up a kiosk in the living/dining room of the new housing unit. For the moment this dwelling has not been modified; 
FIGURA 7. IMPACTO DEL QUIOSCO EN EL USO RESIDENCIAL

FIGURE 7. THE IMPACT OF THE KIOSK ON RESIDENTIAL FUNCTIONS

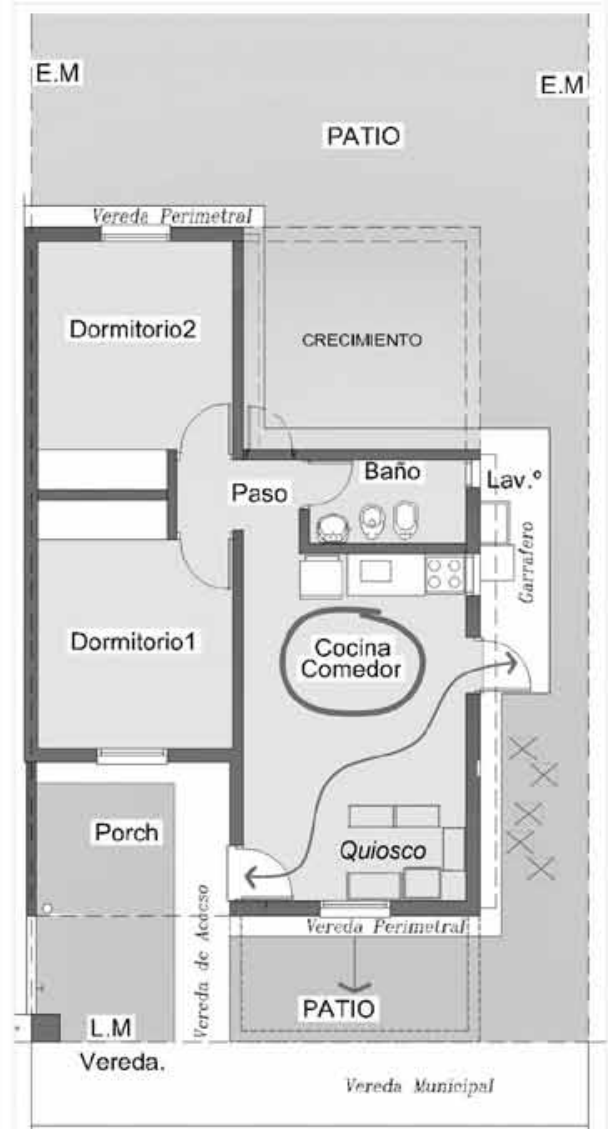

Fuente: Elaboración propia.

Source: Elaborated by the authors
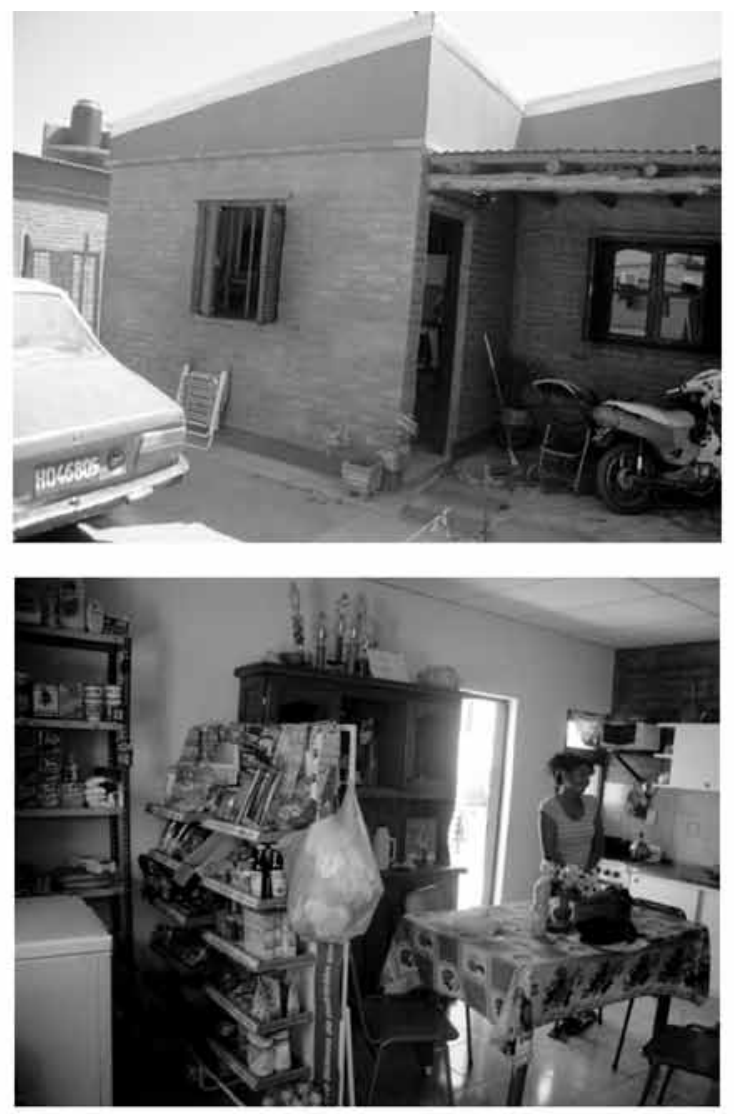
Locales

actividad

productiva

Depósito

de

productos

para

reposición

Futura

ampliacion

hasta la

L.M.

ARTICLE: Social housing and survival skills.appropriate solutions provided by a case study 
FIGURA 8. TABLA SÍNTESIS DE LOS CASOS ANALIZADOS

\begin{tabular}{|c|c|c|c|c|c|c|}
\hline & $\begin{array}{l}\text { Composición del } \\
\text { hogar }\end{array}$ & $\begin{array}{l}\text { Actividad } \\
\text { productiva }\end{array}$ & $\begin{array}{l}\text { Lugar } \\
\text { asignado en } \\
\text { la vivienda }\end{array}$ & $\begin{array}{l}\text { Tipo de } \\
\text { vivienda }\end{array}$ & $\begin{array}{l}\text { Remodelación } \\
\text { efectuada }\end{array}$ & $\begin{array}{l}\text { Remodelación a } \\
\text { realizar }\end{array}$ \\
\hline Caso 1 & $\begin{array}{l}\text { Matrimonio } \\
\text { adulto, } 3 \text { hijos }\end{array}$ & Rotisería & $\begin{array}{l}\text { Hall de } \\
\text { acceso } \\
\text { externo }\end{array}$ & $\begin{array}{l}2 \text { dormitorios } \\
\text { entre } \\
\text { medianeras }\end{array}$ & $\begin{array}{l}\text { Cerramiento del hall } \\
\text { con mampostería, } \\
\text { apertura de vano } \\
\text { al exterior y puerta } \\
\text { para conexión con el } \\
\text { estar-comedor }\end{array}$ & $\begin{array}{l}\text { Ampliación del hall } \\
\text { hasta la L.M. }\end{array}$ \\
\hline Caso 2 & $\begin{array}{l}\text { Matrimonio joven, } \\
1 \text { hijo menor y } 1 \text { en } \\
\text { gestación }\end{array}$ & quiosco & 1 dormitorio & $\begin{array}{l}3 \text { dormitorios } \\
\text { en esquina }\end{array}$ & $\begin{array}{l}\text { Toldo, escalones en } \\
\text { vereda publica }\end{array}$ & $\begin{array}{l}\text { Colocación de } \\
\text { puerta de acceso }\end{array}$ \\
\hline Caso 3 & $\begin{array}{l}\text { Matrimonio, joven, } \\
\text { sin hijos. }\end{array}$ & $\begin{array}{l}\text { Taller de } \\
\text { motos y } \\
\text { bicicletas }\end{array}$ & $\begin{array}{l}\text { Paso } \\
\text { exterior-patio }\end{array}$ & $\begin{array}{l}2 \text { dormitorios } \\
\text { entre } \\
\text { medianeras }\end{array}$ & $\begin{array}{l}\text { Levantamiento del } \\
\text { muro divisorio de } \\
\text { predio y cerramiento } \\
\text { con tinglado }\end{array}$ & $\begin{array}{l}\text { Delimitación del } \\
\text { área a un sector del } \\
\text { patio para poder } \\
\text { seguir utilizándolo } \\
\text { como tal }\end{array}$ \\
\hline Caso 4 & $\begin{array}{l}\text { Matrimonio joven, } \\
1 \text { hijo menor }\end{array}$ & quiosco & $\begin{array}{l}\text { Estar- } \\
\text { comedor }\end{array}$ & $\begin{array}{l}2 \text { dormitorios } \\
\text { entre } \\
\text { medianeras }\end{array}$ & No hay observaciones & $\begin{array}{l}\text { No hay } \\
\text { observaciones }\end{array}$ \\
\hline
\end{tabular}

Fuente: Elaboración propia en base al trabajo de campo. 
FIGURE 8. SUMMARY OF CASES ANALYZED

\begin{tabular}{|c|c|c|c|c|c|c|}
\hline & $\begin{array}{l}\text { Household } \\
\text { composition }\end{array}$ & $\begin{array}{l}\text { Productive } \\
\text { activity }\end{array}$ & $\begin{array}{l}\text { Location of } \\
\text { business }\end{array}$ & $\begin{array}{l}\text { Housing } \\
\text { typology }\end{array}$ & Modification & Pending expansion \\
\hline Case 1 & $\begin{array}{l}\text { Old marriage, } \\
\text { three adult } \\
\text { children }\end{array}$ & Delicatessen & Outer hall & $\begin{array}{l}\text { Two bed- } \\
\text { rooms: bet- } \\
\text { ween party } \\
\text { walls }\end{array}$ & $\begin{array}{l}\text { Masonry enclosure of } \\
\text { hall; a hollow on the } \\
\text { wall that separates the } \\
\text { housing unit from the } \\
\text { street; and the installa- } \\
\text { tion of a door that leads } \\
\text { to the living/dining } \\
\text { room }\end{array}$ & $\begin{array}{l}\text { Expansion of hall } \\
\text { up to the Municipal } \\
\text { Limit }\end{array}$ \\
\hline Case 2 & $\begin{array}{l}\text { Young marriage, } \\
\text { one children } \\
\text { and one unborn } \\
\text { children }\end{array}$ & Kiosk & $\begin{array}{l}\text { One } \\
\text { bedroom }\end{array}$ & $\begin{array}{l}\text { Three bed- } \\
\text { rooms: cor- } \\
\text { ner location }\end{array}$ & $\begin{array}{l}\text { An awning and a } \\
\text { step in the public } \\
\text { thoroughfare }\end{array}$ & $\begin{array}{l}\text { Installation of an } \\
\text { access door }\end{array}$ \\
\hline Case 3 & $\begin{array}{l}\text { Young marriage, } \\
\text { no children }\end{array}$ & Repair shop & $\begin{array}{l}\text { Outer area, } \\
\text { courtyard }\end{array}$ & $\begin{array}{l}\text { Two bed- } \\
\text { rooms: bet- } \\
\text { ween party } \\
\text { walls }\end{array}$ & $\begin{array}{l}\text { Construction of a divi- } \\
\text { ding wall and a shed }\end{array}$ & $\begin{array}{l}\text { Delimitation of a } \\
\text { dedicated working } \\
\text { area in order to } \\
\text { preserve the use of } \\
\text { the courtyard }\end{array}$ \\
\hline Case 4 & $\begin{array}{l}\text { Young marriage, } \\
\text { one children }\end{array}$ & Kiosk & $\begin{array}{l}\text { Living/dining } \\
\text { room }\end{array}$ & $\begin{array}{l}\text { Two bed- } \\
\text { rooms: bet- } \\
\text { ween party } \\
\text { walls }\end{array}$ & No observations & No observations \\
\hline
\end{tabular}

Source: Elaborated by the authors according to data collected from field research 
cercano, por el cual pagan un alquiler mensual y han abierto el quiosco dentro de la nueva vivien$\mathrm{da}$, el cual fue ubicado en el estar-comedor. Por el momento no hicieron ninguna modificación de los espacios de la vivienda, por lo tanto, el desarrollo de las actividades residenciales se ve afectado por la reducción de este espacio y por la superposición de funciones que representa el quisco dentro del ambiente principal de la vivienda (figura 7). Así lo manifestó la madre de la familia:

"...Ellos (los del Programa) nos habían dicho como que era otro ambiente... antes tenía animales y además el quiosco...” "... No me puedo hallar todavía, el espacio es más chico, estamos pensando en ampliar hacia el frente, pero estamos juntando..."

\section{Conclusiones}

Como se desprende del análisis del caso del barrio Don Bosco, una parte considerable de los hogares de bajos recursos utiliza su lugar de vida no sólo como residencia, sino también para actividades económicas informales, que pueden ser vistas como productos de estrategias de sobrevivencia, en la medida que son realizadas para contribuir al conjunto de pequeños ingresos de cada unidad familiar. En este sentido, la disponibilidad de otros tipos de ingresos a cada hogar, que pueden ser formales, ya sea porque algunos de los integrantes de estas unidades domésticas disponen de un empleo público o privado formal de baja remuneración o this means that the development of residential activities is affected by both the reduction of space and the overlapping of functions resulting from the operation of the kiosk within the housing unit (figure 7). According to the householder:

"... We told them (those involved in the Program) how the other space was...before we had animals and run a kiosk..."

“... I do not feel comfortable here yet, this space is smaller, we are thinking of expanding this house, but we are raising money..."

\section{Conclusions}

According to the analysis of the Don Bosco neighborhood, an important number of household on low-incomes use their home not only as a place of residence but also for the development of informal economic activities. These homebased businesses may be seen as the products of survival strategies as they are intended to augment the small income of each household. In this sense the availability of extra types of incomeproducing activities - which range from formal jobs, engagement in low-paid public or private jobs or benefits from social security- should not be exclusively regarded as a means intended to ensure the covering the expenses of family 
algún tipo de ayuda social, no deben ser vistos solo como medios para solventar los gastos de la reproducción familiar, sino también como pequeños activos que permiten el desarrollo de actividades informales complementarias que incrementan los ingresos de cada hogar.

Lo mismo ocurre con las viviendas asignadas por el Estado. Las mismas, a pesar de ser mínimas, no sólo contribuyen a mejorar las condiciones habitacionales de hogares que anteriormente vivían en asentamientos informales muy precarios, sino que también constituyen una ayuda importante para el desarrollo de estas actividades. Aunque, en algunos casos, las características de las nuevas viviendas y las normas de accesibilidad a las mismas, les exigen cambios culturales a los que no siempre se adaptan con facilidad y deben abandonar o modificar actividades productivas que antes realizaban, con el consabido impacto económico que esto acarrea.

Acceder a una vivienda de estas características es para la mayoría de los hogares algo positivo en sus vidas y afirman sentirse satisfechos con la misma. Sin embargo, la realización superpuesta de las actividades económicas dentro de las viviendas, afecta de diferentes maneras el uso residencial de las mismas y sus condiciones de habitabilidad. La mayoría de estos hogares que realizan algún tipo de actividad informal, adaptan la vivienda a estos usos mediante la reasignación de espacios previstos originalmente para usos residenciales mediante reproduction but also as small assets that enable the development of complementary informal activities that increase household income.

The above is also true in the case of the housing units provided by the State. These dwellings, despite having minimum standards of habitability, do not only improve the housing conditions of families who used to live in precarious informal settlements but also contribute to the development of the activities discussed in this research. However there are some cases in which the characteristics of new dwellings and the regulations governing the access to these units demand the adoption of a different cultural system by the new occupants, which is not always easily achieved. Occupants have to abandon or adapt productive activities in which they were previously involved with the corresponding economic impact that this entails.

The access to this type of housing is regarded as a positive experience in the lives of a large number of household members, who feel satisfied with these new dwellings. However the superposing of economic activities in the homes affects the residential use and the habitability condition of these dwellings. Most of these units are adapted in order to perform informal activities through the restructuration or expansion of spaces intended for residential purposes. In most cases households were previously engaged in 
remodelación o ampliación, en muchos casos precarias, de sus viviendas. En la mayor parte de los casos analizados, estos hogares ya realizaban con anterioridad estas actividades o tenían en mente concretarlas una vez que contarán con la nueva vivienda, es decir que ellas podrían haber sido previstas por el Programa.

En general los grupos familiares tienen ideas acerca de cómo querrían que sean los espacios de sus viviendas en cuanto a distribución, usos y dimensiones, para que se adecuen a sus necesidades y tienen planeado en el futuro concretar más modificaciones. Sin embargo, el mayor o menor grado de adaptación de las viviendas para realizar las actividades económicas, depende no sólo del tipo de actividad, sino también de la capacidad económica de los hogares y de sus propios conocimientos en la materia, ya que no cuentan con asesoramiento técnico público, ni tampoco recurren a consultas profesionales para hacerlo. En este sentido, las características de las modificaciones introducidas dependen en gran parte de las trayectorias de vida y los conocimientos que pudieron haber obtenido antes. Por esta razón, las modificaciones en muchos casos, resultan precarias y afectan las condiciones de habitabilidad de las nuevas viviendas. La mayor parte de los integrantes de las unidades familiares entrevistadas no perciben como un problema y naturalizan las mezclas de funciones de habitar y trabajar en un mismo espacio, porque han hecho esto siempre y no these activities or hoped to set up a business upon receiving a new housing unit. This suggests that these intentions could have been foreseen by the Program.

In general family groups have some ideas about the physical appearance of dwellings in terms of the distribution, use and dimension required to serve their needs and they are planning further modifications. However the adaptation of dwellings depends not only on the type of business activity but also on the economic capacity of households and their knowledge on the subject as they have no access to technical-public advice and do not ask for professional help on the matter. In this sense the characteristics of modifications depend on the experience and knowledge of users. This is why in most cases these physical alterations are poor in quality and affect the habitability conditions of new housing units. A large part of interviewed household members do not perceive problems with this issue and regard the mixture of labor and dwelling functions as a normal fact since they have lived under such a system their entire lives. They have no previous experience to understand the extent to which their quality of life and the comfort level of dwellings are affected by the overlapping of these functions.

Housing policies aimed at these social sectors should be aware of this reality in order to provide 
tienen experiencia previa para entender como esta superposición afecta la calidad de vida residencial.

La política habitacional orientada a estos sectores sociales debe asumir esta realidad para brindar soluciones más integrales y adecuadas a sus necesidades. Sin dudas que lo deseable es que el Estado continúe avanzando en políticas de creación de empleos formales, que cuenten con protección social y con niveles de ingresos adecuados para que estos sectores sociales no deban recurrir a actividades informales adicionales. Sin embargo, aunque el Estado continúe con políticas de formalización y mejoramiento del empleo, el problema, por su magnitud persistirá aún por mucho tiempo ${ }^{26}$ y por lo tanto, es necesario que la política habitacional asuma esta realidad para adecuar sus soluciones al problema.

La concepción sectorial de vivienda que promueve hoy la política habitacional no da respuestas al desarrollo de múltiples y cambiantes actividades de subsistencia. No es posible concebir a la vivienda de estos sectores sociales como un sistema cerrado acabado en sí mismo, exclusivamente para habitar, sino como un objeto en proceso de modificación constante por sus propios usuarios, a partir de sus situaciones productivas particulares.

26 El gobierno acaba de sancionar una ley de promoción del empleo registrado que apunta a solucionar problemas de las microempresas para que sus trabajadores informales tengan protección social. Mediante esta ley se espera reducir el porcentaje actual de la informalidad laboral del $33 \%$ al $28 \%$ en dos años, mediante la regularización de cerca de 600.000 trabajadores informales. more comprehensive and targeted solutions to their needs. It would be desirable for the State to move forward in the design of policies intended to stimulate the creation of formal jobs that provide social security and adequate income, thus preventing people from engaging in complementary informal activities. However even though the State is working on the implementation of policies focused on the improvement and formalization of employment, this issue due to its size will still persist for a long time $e^{26}$. This suggests that housing policies should be aware of this reality in order to provide tailored solutions to this problem.

The sectoral approach to housing promoted by housing policies does not provide answers to the development of multiple and changing survival activities. It is not possible to think of low-income housingasasystemintended exclusively for dwelling purposes; these units should also be regarded as structures that are constantly altered by their owners on the basis of specific productive activities.

In order to arrive at a satisfactory response, the whole set offactors that impact on the needs of these

26 The government has just enacted a law intended to promote formal labor and solve the problems of microbusinesses whose workers are not enrolled in the social security system. This law is expected to reduce informal labor rates from 33 to 28 percent within a two-year period through the regularization of 600,000 informal workers. 
Para llegar a una respuesta más adecuada se debería estudiar a fondo el conjunto de factores que inciden en la necesidad de estos hogares y no dar por supuesto que usarán la vivienda sólo para habitar. En particular, de aquellos hogares que esperan contar con una nueva vivienda para realizar prácticas económicas informales dentro de la misma. Para estos hogares, contar con un sitio para desarrollar actividades económicas que permitan la reproducción de sus vidas, es tan importante como lo son los espacios del habitar.

A la luz de este análisis, se pueden hacer algunas recomendaciones:

Al nivel de la política habitacional:

- Identificar y estudiar la problemática de la informalidad en diferentes contextos urbanos y territoriales, en particular el impacto que tienen las actividades económicas informales en las viviendas y el hábitat de los sectores de bajos ingresos.

- Propiciar ámbitos donde confluyan investigaciones académicas realizadas desde distintos campos disciplinarios y también prácticas experimentales, tendientes a rever el paradigma tradicional de resolución de la vivienda social y a asumir la multidimensionalidad del problema habitacional de los sectores de bajos ingresos.

Ambas recomendaciones podrían implementarse en el marco del Plan Nacional de Ciencia, households should be thoroughly analyzed. This exercise includes avoiding thinking of housing as a unit intended exclusively for dwelling purposes; particularly in the case of those families who are waiting to be granted housing in order develop home-based informal activities. In this sense owning a space dedicated for the development of economic activities that enable the reproduction of life is as important as owning a property.

This analysis suggests the following recommendations:

Suggestions at housing policy level:

- Identify and analyze the informality issue across a range of urban and territorial contexts, especially within the context of the impact of home-basedinformalactivities on the dwellings and habitat of low-income segments.

- Create spaces for the convergence of research from within different academic fields and experimental practices. The spirit of this initiative is to review the traditional paradigm related to the solution of housing needs and address the multidimensionality of the housing issue in low-income segments.

These recommendations may be implemented within the framework of the Innovative Argentina 
Tecnología e Innovación "Argentina Innovadora 2020", formulado por el Ministerio de Ciencia, Tecnología e Innovación Productiva en 2012, el cual contempla líneas de finamiento para hábitat social que promueven la articulación con sectores productivos y académicos.

Al nivel de los programas habitacionales:

- Generar programas integrales adecuados a este tipo de problemas, que además de resolver lasnecesidades habitacionales, contemple al conjunto de dimensiones que afectan el hábitat digno.

- Contemplar en estos programas la organización de espacios comunitarios barriales (mercados) para el desarrollo de estas actividades económicas, así como capacitación a quienes practican estas actividades con la finalidad de integrarlos progresivamente a la economía formal.

- Realizar seguimientos luego de asignadas las viviendas y asesoramientos permanentes para las modificaciones y reformas que emprenden los destinatarios.

Estas recomendaciones podrían implementarse diseñando a escala municipal intervenciones integrales a partir de planes de actuación urbana que articulen programas habitacionales, ambientales, urbanísticos y sociales y económicos productivos (economía social), implementados normalmente de manera independiente y de forma sectorial. Adicionalmente se recomienda que estos planes de actuación sean formulados metodológicamente
2020: National Plan Science, Technology and Innovation, developed by the Ministry of Science, Technology and Productive Innovation in 2012, which is intended to create a bridge between productive and academic spheres.

Suggestions at housing program level:

- Generate comprehensive programs specifically designed to deal with this kind of issue, solve housing needs and address the different dimensions affecting decent housing.

- Consider the establishment of community spaces at neighborhood level (markets) intended for both the development of this type of economic activity and the training of those involved in informal businesses. The goal is to integrate these individuals into formal economy activities on a gradual basis.

- Conduct follow-up of delivered housing units and provide constant advice to dwellers on all mattersrelated tomodificationsandalterations.

These suggestions may be implemented through the design of comprehensive municipal interventions intended to articulate housing, environmental, urban and social economy programs; these initiatives should be implemented on an independent and sectoral basis. Likewise, these action plans should be methodologically prepared according 
desde el enfoque de la planificación estratégica y permitan la participación ciudadana.

Al nivel de los proyectos habitacionales:

- Incorporar criterios de flexibilidad en el diseño de las viviendas, de modo tal que las mismas contengan y permitan distintas distribuciones funcionales y áreas de trabajo que no interfieran en la vida privada de los hogares.

- Contemplar la participación de los destinatarios en la definición de las necesidades particulares de los hogares y la resolución de las viviendas.

- Incorporar una visión integral en la resolución de la vivienda, dejando de lado el paradigma sectorial que considera que la resolución de la necesidad habitacional se reduce exclusivamente a la provisión de una vivienda estandarizada y asumiendo que la vivienda es un sistema complejo que debe resolver una serie de otras actividades sumadas a la función básica de alojamiento, entendiendo en este contexto al hogar no solo como unidad de reproductiva sino también productiva.

Estas recomendaciones requieren cambiar la forma tradicional de diseño habitacional estandarizado y economicista que promueven la política habitacional y las empresas constructoras contratistas del Estado. Podrían implementarse mediante la articulación de la política habitacional con el campo académico, a través de la apertura de espacios de to strategic guidelines and include the participation of the civil society.

Suggestions at housing project level:

- Flexibility in the design of housing units; this involves the functional distribution of dwellings and the inclusion of working areas in order to preserve private life.

- Include the participation of householders in the definition of housing needs.

- The developmentof a comprehensive approach to the resolution of housing needs and ignore the sectoral paradigm that relates these requirements to the provision of standardized dwellings. Such an approach should be based on the assumption that the housing unit is a complexsystemintended to solve different types of needs. In this context, dwellings are regarded both as reproductive and productive units.

The goal of the above suggestions is to change the traditional standardized and economyfocused design of dwellings promoted by housing policies and private government contractors. These recommendations may be implemented through the articulation of housing policies and the academic field and the creation of spaces for experimentation and innovation within the context of housing and social habitat. 
experimentaciones e innovaciones en el campo proyectual de la vivienda y el hábitat social.

\section{Bibliografía}

BARRET0, Miguel. La perspectiva integradora de los derechos. Actuar desde las disciplinas pensando desde la complejidad. En: Encuentro de la Red Universitaria Latinoamericana de Cátedras de Vivienda (13, 2007, Valparaíso, Chile). Santiago, Chile, Instituto de la Vivienda de la Facultad de Arquitectura y Urbanismo de la Universidad de Chile y Subsecretaria de Desarrollo Regional y Administrativo, Ministerio del Interior, Gobierno de Chile. 2008. ISBN 978-956-19-0608-2. pp. 69-76.

--- El concepto de "hábitat digno" como meta de una política integral de áreas urbanas deficitarias críticas, para la integración social desde los derechos humanos. [En línea]. Revista INVI. 25(69): 161-187, agosto 2010. ISSN 07181299. Disponible en: http://dx.doi.org/10.4067/ S0718-83582010000200005

--- Cambios y continuidades en la política de vivienda Argentina (2003-2007). Cuadernos de Vivienda y Urbanismo. 5(9): 12-30, enero 2012. ISSN 2027-2103.

BARRETO, Miguel y ALCALÁ, Laura. Cambios en las prestaciones urbano-ambientales de la política habitacional argentina. Reflexiones a partir de cuatro programas orientados a población en situación de pobreza del Gran Resistencia. En:
Jornada Internacional de Vivienda Social $\left(5^{\circ}\right.$, 2007, Valparaíso, Chile). V Jornada Internacional de Vivienda Social: el derecho a la ciudad y a la vivienda: propuestas y desafíos en la realidad actual. Santiago, Chile, Instituto de la Vivienda de la Facultad de Arquitectura y Urbanismo de la Universidad de Chile y Subsecretaria de Desarrollo Regional y Administrativo, Ministerio del Interior, Gobierno de Chile. 2008. ISBN 978-95619-0589-4. pp. 51-63.

BERTRANOU, Fabio y CASANOVA, Luis. Informalidad laboral en Argentina: segmentos críticos y políticas para la formalización. [En línea]. Buenos Aires, OIT. 2013. [Fecha de consulta: 12 marzo 2014]. Disponible en: http://www.ilo.org/buenosaires/publicaciones/WCMS_234705/lang--es/ index.htm.

CARIOLA, Cecilia. Sobrevivir en la pobreza: el fin de una ilusión. Centro de Estudios del Desarrollo (CENDES). 1992. 233 p. ISBN 978-980-31-7015-8.

CHEN, Martha. La economía informal: definiciones, teorías y políticas. [En línea]. Cambridge, Estados Unidos, WIEGO. 2012. ISBN 978-92-95095-410. [Fecha de consulta: 10 marzo 2014]. Disponible en: http://wiego.org/sites/wiego.org/files/publications/files/Chen-Informal-Economy-DefinitionsWIEGO-WP1-Espanol.pdf

CORAGGI0, José Luis. Una perspectiva alternativa para la economía social: de la economía popular a la economía del trabajo. En: CORAGGIO, José Luis, org. La economía social desde la periferia. Contribuciones latinoamericanas. Buenos 
Aires, Universidad Nacional de General Sarmiento, Editorial Altamira. 2007. p. 165-194. Colección lecturas sobre economía social. ISBN 978-987-9017-71-5.

HINTZE, Susana. Capital social y estrategias de supervivencia. Reflexiones sobre el "capital social de los pobres". En: DANANI, Claudia, comp. Política social y economía social: debates fundamentales. Buenos Aires, Argentina, Altamira. 2004. p. 87116. Colección de Lecturas sobre Economía Social. ISBN 978-987-90-1733-1.

--- Estrategias alimentarias de sobrevivencia. Un estudio de caso en el Gran Buenos Aires. Buenos Aires, Argentina, Centro Editor de América Latina. 1989. 184 p., vol. 2. ISBN 978-950-25-1540-3

JACOBS, Jane. Muerte y vida de las grandes ciudades. Madrid, Península.1973.

JELIN, Elizabeth; MERCADO, Matilde y WYCZYKIER, Gabriela. El trabajo a domicilio en Argentina: informe final de investigación. [En línea]. OIT. Octubre, 1998. [Fecha de consulta: 13 marzo 2014]. Disponible en: http://www.ilo.org/employment/ Whatwedo/Publications/WCMS_123600/lang-es/index.htm.

LE CORBUSIER. Principios de urbanismo. Barcelona, Planeta-De Agostini. 1986. 151 p. Obras Maestras del Pensamiento Contemporáneo. ISBN 84-395-0137-4.

LEFEBVRE, Henry. De lo rural a lo urbano. Barcelona, Península. 1971. 268 p. Historia/Ciencia/Sociedad 79.
ONU Hábitat. El derecho a una vivienda adecuada. Folletos informativos sobre los derechos humanos. (21 Rev. 1), 2010. ISSN 1014-5567.

PORTES, Alejandro y HALLER, William. La economía informal. [En línea]. Santiago, CEPAL. 2004. Serie Políticas Sociales 100 [Fecha de consulta: 17 marzo 2014]. Disponible en: http://www.eclac.cl/ publicaciones/xml/5/20845/sps100_lcl2218.pdf.

SALAS, Julián. Tugurización y necesidades de habitabilidad básica, rémoras a la cohesión social en Latinoamérica. Pensamiento Iberoamericano. (1): 207-230, 2007. ISSN 0212-0208. 